Karolina Sidowska*

University of Lodz

\title{
APPROACHES TOWARDS SHAME IN CONTEMPORARY POLISH LITERATURE
}

\begin{abstract}
This article focuses on literary approaches to the emotion of shame. My thesis is that literature can be perceived as a tool for overcoming feelings of shame, as it is capable of expressing even the most intimate human experiences in aesthetic terms, outside stereotypical moral judgments. From this perspective I discuss exhibitionistic tendencies on the author's part and complementary voyeuristic impulses on the part of the reader. In this context I then consider the phenomenon of literary provocation and its function to then analyse two examples from Polish contemporary literature: Polka by M. Gretkowska - a literary journal of pregnancy - and Lovetown by M. Witkowski. Both, in my opinion, offer interesting aesthetic views on intimate but relevant aspects of everyday life.
\end{abstract}

Key words: aesthetics, shame, contemporary Polish literature, experience

In her famous essay Reading for Life Martha Nussbaum proposes a theory stating that reading is an ethical act which holds significant implications for the reader's entire life and functioning within the community. (Nussbaum 1990) The essay title might therefore be understood as a summons to apply the knowledge and experience gained from reading in order to live a better, fuller, more responsible and conscious life. Another interpretation is that Nussbaum places reading on the same level as processes and activities indispensable to maintaining life in its basic, biological form; to paraphrase - that there is no life without reading. Or, at least, no life worthy of the name. Undoubtedly, despite distressing reports on the decrease

* German Philology, Univesity of Lodz, ul. Pomorska 171/173, 90-236 Lodz, e-mail: karolinasidowska@wp.pl 
of readership, there still are people for whom this high-minded statement rings true and who indeed cannot imagine a day without reading. For them, reading is a way of life. This phenomenon, or more broadly, readers' reception of literary works, has been a subject of interest to literary scholars - professional readers, who endeavour to explain the phenomenon of reading from a scientific perspective, but still not without certain personal sentiments. ${ }^{1}$

The scope and range of readership studies illustrates the scale and importance of the phenomenon of reading. Writing, as much as it remains a complementary counterpart of reading, seems to be a less egalitarian pursuit - or, at least, this has been the case until recently. The circle of writers has always been considerably narrower than that of readers, even if we include the scores of journals, memoirs and poems written purely for personal pleasure or stored in desk drawers; works that never made it into public consciousness. In the era of websites, blogs and Internet forums, reaching potential readers is simple enough, which presents an opportunity for many new writers, including amateurs or so-called 'scribblers', whose creations would not previously have passed editorial filters. One could question the value of this artistic democratisation, or repeat after Julian Tuwim: "Blessed is he who has nothing to say and does not put this fact into words". (Tuwim 1987) Finally, one could conclude that just as writer's block exists, there also exists a certain imperative to write (or in some cases, an imperative to self-promote, if one was to treat the phenomenon less warmly). This desire for expression, for marking one's presence or even for bringing intimate experiences and reflections into the light includes an element of exhibitionism. We are all exhibitionists and voyeurs by nature - those are natural instincts, which only become a pathology when they turn into an obsession: "Every human being is motivated by that deep desire to be seen, to have attention paid to them, to be noticed and to be heard." (Carr-Gomm 2012: 198) Furthermore, is it possible to imagine creative activity without those instincts? Is not every author an exhibitionist in a way, one who - to follow the Latin etymology -

1 Diverse texts can be placed in this category - philosophical studies, such as Roland Barthes' The Pleasure of the Text; literary studies by scholars such as Anna Burzyńska (Lekturografia. Filozofia czytania według Jacques'a Derridy, in: "Pamiętnik Literacki" 1/2000, Literatura jako sztuka uwodzenia: przyczynek do tematu in: "Teksty Drugie" 4/1998; Ciało w bibliotece in: "Teksty Drugie" 6/2002; Teoria i lektura: niebezpieczne zwiazki, "Pamiętnik Literacki" 1/2003) or Ryszard Koziołek (Maski czytania, in: Intymność wyrażona, ed. M. Kisiel, M. Tramer, University of Silesia Press, Katowice 2006) or essays and literary takes on the subject such as Alberto Manguel's A History of Reading or - from the Polish corner - Młodszy ksiegowy [The Junior Clerk] by Jacek Dehnel, WAB, Warsaw 2013. 
exhibits, shows, uncovers in public? Not perhaps by undressing in public, but quite on the contrary - by dressing truths up with words and literary conventions? In this model of exhibitionism, uncovering is complemented by covering, and what we are shown only appears to be a faithful representation of what lurks in the creator's soul. Searching in a literary work for a direct expression of the creator's experience, as Dilthey would have done, over a century after the anti-Positivist turn would be a slightly amusing andnaïve anachronism. A limited degree of trust is advisable; even more limited, if the text seems to be a "sincere" autobiographical account with first-person narration. In reality, as Erazm Kuźma points out - "pisanie jest zawsze zdradą wnętrza, zdradą w tym sensie, że to, co uchodzi za prawdziwe wnętrze, zastępuje się sztucznym." [English: "writing is always a betrayal of the inner sphere as much as what seems to be the real inner sphere is replaced by an artificial construct"] (Kuźma 2006: 11).

The artist's exhibitionistic impulse can take the form of a provocation - a conscious and deliberate infringement of accepted norms. Frequently such actions are motivated by nothing more than marketing; the aim is to create a media buzz and increase sales. It would, nevertheless, be an oversimplification to say that there can be no other dimensions to it. Provocative texts can function as doors, through which the reader can access those areas of reality which otherwise remain off-limits, on the margins of consciousness, never articulated. By dealing with taboo subjects they enrich knowledge, deepen understanding and are a school of sensibility. Thanks to those literary provocations, those not calculated solely to create a media shock, but in order to communicate valid truths, some experiences and phenomena can trickle down from the realities of life into the realm of acceptable literary subject matter. As a result, not just the readers' horizons open up, but language itself is enriched - even if those more conservative among us tend to view this as pollution of discourse. We can trace this paradigm to the sexual revolution which took place in the second half of the twentieth century and has lead to enriching literature and deepening artistic and ethical sensibilities, largely due to artists' rejection of stale social models and conventions (cf. Sadkowski 1987). Naturally, literary provocation is not an invention of the $20^{\text {th }}$ and $21^{\text {st }}$ centuries: throughout history, authors of scandalous works have faced considerable sanctions, including a ban on publication and imprisonment. ${ }^{2}$ Today's courts of justice rarely get involved, unless a book is seen as offensive towards a specific, personally offended

2 Probably the best-known case is that of Marquis de Sade's lengthy imprisonment in the Bastille for offending public morality. 
individual. Literary criticism has liberalised along with its subject matter; the limits of its influence has narrowed. Large numbers of readers consume that which is fashionable and trendy. The public, accustomed to drastic scenes and images present in the media, politics, arts, reacts to provocative gestures and words with a decreased sensitivity. This natural reaction is akin to a "blasé" condition - a result of long-term and intense nervous stimulation, described by Georg Simmel already at the beginning of the $20^{\text {th }}$ century. (Simmel 2006: 120) These days' authors are rarely accused of propagating immoral attitudes or breaking the rules of good taste. Therefore we should ask if there is still anything a writer is not "supposed to do"? Do any taboo subjects or off-limits aspects of reality exist? Does the depiction of any sphere of life require a courageous transgression of universally accepted norms, or a certain "shamelessness" in depicting a given theme? Is the lack of shame to be understood in a positive sense, as a kind of openness and sincerity (not without its own problems) ${ }^{3}$ These questions belong to the field of creativity psychology rather than literary studies. Therefore on the following pages I will attempt to look not at the psychology of authors, but at selected contemporary literary texts which tackle "shameful", intimate, overlooked themes and examine the function - or functions - of literary works of this type. How is shame (or shamelessness) depicted in literature? Can one talk about known 'shameful' motifs and what are the implications of their existence in everyday, non-literary reality?

Shame is an emotion that appears at the moment of realising that one has infringed upon the norms or conventions adopted in a given environment. (Demmerling/Landweer 2007) These norms and rules vary, of course, with each time period, geographic location or social class, which is why many researchers treat shame as a cultural phenomenon. However, its universal presence - despite varying forms of expression - suggests the need to situate the ability to feel ashamed in the basic anthropological human toolset. An important, but not indispensable factor is the pres-

3 It is worthwhile mentioning that the differentiation between sincerity and authenticity in existential philosophy; for instance, in Sartre's view sincerity, as a way of adopting a specific identity, "being something", is a priori ill-intentioned as an escape from the irremovable duality characterising being-for-itself, which must constantly define itself against the surrounding beings. Therefore „autentyczność musi być projektem znacznie bardziej radykalnym, wyjściem poza krąg złudzeń wspieranych przez szczerość, zaakceptowaniem własnej nicości jako jedynej cechy przysługującej podmiotowi." ["authenticity must be a project more radical, a step outside the circle of illusions supported by sincerity, an acceptance of one's nothingness as the sole characteristic."] (Warchala 2006: 11). 
ence of witnesses: they personify the unchanging nature of rules that have been broken. Still, even if a witness, judge or prosecutor is not present, the norms and prohibitions are always present in the consciousness - or subconsciousness - of the transgressing individual. The gaze of the Other, in which, to quote Sartre, the experience of being is realised, is a constant of being, even if the Other is not given in its physical form: "Thus shame is shame of oneself before the Other; these two structures are inseparable. But at the same time I need the Other in order to realize fully all the structures of my being. The For-itself refers to For-others." ${ }^{4}$ (Sartre 2003: 246) Max Scheler, author of an exhaustive study on the feeling of shame, derives it from the duality of human nature, which comprises of a spiritual component, a reflective component and the bodily, organic component which places human beings close to animals. It is the things that are fragile, mortal, subject to the laws of biology and therefore opposed to human values and ideas that most frequently cause shame and repulsion. (Menninghaus 2009: 177) A quick look at the repertoire of most popular 'shameful' literary motifs across the centuries confirms this: we are most often ashamed of nudity, bodily anomalies and diseases, physiological processes, sex and old age. Naturally shame can also have a moral dimension, a social dimension, it can result from an inadequate skill or incompetence, unethical behaviour, treason etc. Such a definition of shame, related to a personal sense of honour, appears in the writings of Artistotle and Plato, and dominates practically until the end of the $19^{\text {th }}$ century, at which time it began to be associated mainly with the body and sexuality, especially female. (Frevert 2013: 24) Puritan upbringing and control was intended to tame the sexuality of women, who in Scheler's view are characterised by a less acute (than in men) sense of shame. (Scheler 2003: 32) Since the 1850s these trends have been countered by emancipatory movements, strengthened between the world wars and then blossoming within the feminist wave of the 1960s. Feminist literary criticism directed public attention not only to stereotypical and patriarchal renditions of women, but also to the absence of any literary depictions of numerous vital aspects of female existence especially those related to the body and female physiology, 'impure' and

${ }^{4}$ Cf. the following passage: "Every look directed toward me is manifested in connection with the appearance of a sensible form in our perceptive field, but contrary to what might be expected, it is not connected with any determined form. Of course what most often manifests a look is the convergence of two ocular globes in my direction. But the look will be given just as well on occasion when there is a rustling of branches, or the sound of a footstep followed by silence, or the slight opening of a shutter, or a light movement of a curtain." (Sartre 2003: 281) 
unfit for print. The literature of the end of the $20^{\text {th }}$ and the beginning of the $21^{\text {st }}$ centuries makes up for those deficiencies and refuses to be reduced to the derisive genre of "menstruatory literature" ${ }^{5}$. (Nęcka 2006)

One of the most important women's experiences - pregnancy and birth - has only recently become a major theme in Polish literature, making its appearance in Anna Nasiłowska's Domino. Traktat o narodzinach (Dominoes. A Treatise on Birth) and Księga poczatku (Book of the Beginning) by the same author, as well as in Polka by Manuela Gretkowska. Gretkowska, labelled the provocateur of Polish literature since her debut in early 1990s, does not shock in her pregnancy journal as much as she surprises the reader with the directness and simplicity of description, not devoid of physiological or anatomical detail, but not seeking to needlessly impose them on the reader. Few situations justify concentrating on bodily sensations and signals as much as pregnancy does. This particular diary of pregnancy may not have been written for personal purposes, but with readers in mind, nevertheless the impression of sincerity is most suggestive. The author-narrator reveals herself in two ways - by describing her fears, doubts, and thoughts and by describing how her body changes shape. Notably, however bold and striking the images, the narrator points out: "Intimate things are those in one's head". (Gretkowska 2012: 276) This statement, as indeed the entire journal, draws new boundaries of the intimate - and consequently, new boundaries of shame, even if the feeling is not unknown to the protagonist in the most commonplace of situations:

Nie pośliznąć się, nie pośliznąć. Docieram do sklepu. Z koszyczkiem obchodzę półki. W naszym bezzapachowym sklepie wykręca mnie odór wody. Flejtuchowaty pijak wybiera cukierki. Odwracam się ze wstrętem, chyba za ostentacyjnie. Znowu się na niego natykam przy warzywach. I nagle... Prrr - elegancka dama z koszyczkiem rozpierdza się. Nie mogę powstrzymać nagłej eksplozji. Pijak spogląda na mnie z rozbawieniem. Nie rozepnę kożucha i nie pokażę sprawcy, naciskającego spust gazów. Wstyd okropny. (Gretkowska 2012: 244)

[Note to self: do not slip, do not trip. I reach the store. I circle the shelves, shopping basket in hand. In our odourless shop I am repulsed even by the smell of water. A grubby drunk chooses sweets. I turn my back with disgust, a little too ostentatiously, perhaps. I bump into him again by the vegetables. And suddenly... Prtt! - elegant basket lady farts: I can't stop a sudden explosion. The drunk looks at me with amusement. I won't undo my overcoat and present the culprit who pushed the trigger. Dreadful embarrassment. (Gretkowska 2012: 244, English translation by the author of the article]

5 Term coined by Jan Błoński. 
The faux pas may have had natural causes and been unavoidable, still the feeling of shame is automatic. Its source is not just the transgression of accepted standards of behaviour, but also the loss of control over one's body and the observation of cultural constructs quickly perishing in confrontation with biological processes:

Człowiek strasznie stara się być człowiekiem. Nie posikać się, nie posrać, nie zarzygać. Udawać cywilizowanego czyścioszka, panującego nad odruchami. Człowiek jest chyba bardzo znerwicowany sobą samym, tak zaciskając zwieracz i pęcherz. Biegnę do łazienki. (Gretkowska 2012: 272)

Humans try so hard to be human. Don't pee yourself, don't shit yourself, don't puke. Pretend to be squeaky clean, civilised and in control over your instincts. Humans must be very stressed, clenching their orifices all the time. I run to the bathroom. (Gretkowska 2012: 272, English translation by the author of the article)

More similarly self-reflective passages can be found in Polka, and they should not perhaps be reduced to questioning shame or rejecting it as baseless. The originality lies rather in the openness towards discussing it, surprising in the case of an emotion which tempts us to hide from the inquisitive gaze of others. To admit to feeling ashamed or embarrassed, even to oneself, and to conduct a detailed analysis of potential causes is to disarm and neutralise the sensation. The ability to see oneself from a certain distance is also important, even if - in the most extreme cases it displays traits of a split personality: "The pure ego, unstained by physiology has escaped somewhere towards the top of my head. From there it watches the body contorted by disgust and shame" (Gretkowska 2012: 66, English translation). Similarly in another passage: "I get up at night with a bad taste in the mouth. Self-disgust. I run to the toilet. How does one like someone, for whom the only goal is getting up and having a pee? I've caught myself having this sole need at three in the morning, the rest of me is sleeping or mocking me." (Gretkowska 2012: 147) Similarly, often very intimate revelations are usually accompanied by a healthy dose of self-irony, expressed in explicit phrases typical for Gretkowska: "I feel like a female about to spawn" (Gretkowska 2012: 342), or: "The body pushes out what it can: haemorrhoids, nosebleeds. A general rehearsal before pushing out Pola." (Gretkowska 2012: 331)

Humour and wit have for centuries successfully neutralised shame, especially that relating to the sphere of the body. An example of this can be the entire genre of medieval and Renaissance picaresque literature. Laughter liberates all those engaged in a shameful situation: the offender as well 
as witnesses of the shameful act, often highly embarrassed themselves. A humorous approach or witty convention creates a healthy distance and weakens the gravitas of the offense, as well as, possibly, the severity of any sanctions. On the other end, socially adopted rules and adherence to them lose their power in situations of extreme closeness, governed primarily by the rules established by the partners in a given intimate relationship. Paradoxically, intimacy does not exclude humour, but rather widens its context. In Gretkowska's book both remain in a state of balance. The personal experience of pregnancy (from an anthropological point of view - a key human experience), frequently eliminated from public discourse, receives a treatment devoid of false modesty or embarrassment, but also devoid of stereotypical pathos. Acceptance for the biological, animalistic dimension of this experience, expressed in colloquial and occasionally vulgar expressions, ${ }^{6}$ does not diminish its metaphysical dimension - on the contrary, underlines the complexity of experience and constitutes a step forward in literary explorations of important regions of human existence.

It would be difficult to assess Gretkowska's book as scandalous and therefore shameless; evaluations of this kind were evoked in 2004 by the appearance of the "first Polish gay novel"7 by Michał Witkowski. I refer of course to the infamous Lovetown, in which the author's intent was to be a new Decameron, a "Great Atlas of Polish Faggots". We might treat those arrogant declarations with a pinch of salt, still their forcefulness proves the author's unrestrained approach to the "slippery" subject of homosexuality. It also invokes the long tradition of depicting homosexuality in the history of literature. The deliberate openness with which Witkowski describes the life of aging gay men is reminiscent of a literary coming out. We have here a clear aim to end the demonisation of homosexuality, to revise conservative, small-town patterns of thinking, and a yearning for the possibility of free expression, for life without shame. This state of no shame would then represent not a moral downfall, but a utopian idea of return to the state of paradise-like innocence, when human beings knew nothing

${ }^{6}$ Cf. Sadkowski's remarks on style related to the sexual revolution: “Coraz jaśniejsze staje się natomiast, że unikanie dosadności językowej tam, gdzie jest ona zasadna, gdzie jest odzwierciedleniem i ewokacją rzeczywistości językowej i psychologiczno-obyczajowej, jest artystycznym fałszem." [It is becoming clear that avoiding frank language where it is justified, where it is a reflection and evocation of linguistic, social and psychological reality, is artistic falsity.] (Sadkowski 1987: 337)

7 This label has been attached to Witkowski's book somewhat hastily. Polish literature dealing with similar themes has previously existed, for instance the 1980 Rudolf by Marian Pankowski. 
of sin or moral evaluations. It would therefore mean a return to honesty and natural behaviour, as it occurs in children and animals. Such a vision stands however in stark contrast with the theatricality and artificiality of the twisted poses of the characters of Lovetown, who anyway do not identify with any slogans calling for emancipation of sexual minorities in the political debate about equal rights. Acting naturally feels alien to them and they do not wish to be natural any more than they wish to gain social acceptance or care for unambiguous, universal social standards. They do not care for authenticity:

Neither has ever heard of plastic surgery or sex-change operations. They get by with a flourish or two of their plain black satchels, which they call 'handbags'. (...) All they have to do is hold their cigarettes a little differently, shave every day, and put their words, their language, to use. For their power lies in their words. They have nothing; whatever they do have they've had to make up, lie up, sing up. (...) They don't want to be women at all; they want to be swishy men. That's how they like it, how they've been their whole lives: pretend femmes. To actually be a woman would be beside the point. What's exciting is the pretending; to actually satisfy their imagination would be... (Witkowski 2011: 12)

The source of excitement is not just the rough sex appeal of "grunts" 8 , but also the act of pretending, masquerading and an ever-present risk factor. Assuming roles and constantly oscillating between different realities and identities defines Witkowski's characters:

Lucretia poses like a dowager countess deprived of her fortune by the vicissitudes of war. She crosses her legs (a pale calf, tattooed with a web of veins, appears between her sock and the cuff of her brown trousers), lights a cigarette, holds the smoke in for a moment, then releases it with a deep sigh, a lady lost in revery. They put on their favourite Anna German record. (Witkowski 2006: 14)

Embarrassment and modesty is just another part of the game, even if it is pretend modesty, fussing and affectation. Shame signals a rule has been broken, marks an awareness of having transgressed the rules in force; it is the very act of breaking rules and social taboos that gives the characters

8 Cf. the following passage: "Grunt is what gives our lives meaning. A grunt is a bull, drunken bull of a man, a macho lowlife, a con man, a top, sometimes a guy walking home through the park, or passed out in a ditch or on a bench at the station or somewhere else completely unexpected (...) Grunt can be homosexual, too, as long as he's simple as an oak and uneducated - because if he finishes school he isn't a real man any more, he's just some intellectual. Grunt can't be someone who puts on airs. He has to have a mug like a thigh - a box covered with hide, the last place where anything can be expressed, least of all feelings!" (Witkowski 2011: 11) 
a shot of adrenalin and excitement. Bataille describes similar experience of transgression in the categories of ecstasy and fear (Bataille 2007: 42), still it seems that shame plays a significant part, too, as a feeling related to fear. In essence shame is a type of fear - fear of exclusion, of rejection by one's environment, but also of betraying oneself (when one breaks the rules which define us in our own eyes). It is a reaction against losing self-control, control of our bodies, emotions or words. ${ }^{9}$ In that sense it serves a protective role for the most internal and intimate sphere of the individual, guarding its boundaries and preventing behaviours contradictory to the essence of a given individual (cf. Chu, de las Heras 1994). At the same time shame has an important cognitive significance. The emergence of the emotion of shame lets us recognise the moment in which we cross a taboo - the moment when transgressing the norm makes it all the clearer in our consciousness. Along with other emotions it is an element of the internal 'early warning system': thanks to it, the rules are constantly confirmed. And only where rules are known, playing the game is possible.

Notably, the oppressive character of the shame experience, its objective unpleasant character, for the protagonists of Lovetown seems to present a value. A masochistic tendency for self-humiliation is characteristic for Patricia and Lucretia: they derive a perverse pleasure from acting weak, submissive and used: "Patricia realizes she's called herself a 'bag lady' and she's delighted at her new joke. Somewhere deep down it contains a trickle of indignity, and Patricia is already planning to drink it, to lick it up like a drop of eggnog from the bottom of a glass. Tonight." (Witkowski 2011: 8) In this context, the feeling of shame loses its negative overtone, it indeed gets questioned. Do the characters really experience shame, or has it been replaced by role play? When they do feel ashamed, it is in entirely different situations and for reasons different from what's expected. Lovetown, picturing just a specific, self-encompassing gay scene - with aging actors past their prime, living on the reminiscences of the past - appears not to concern the psychological inhibitions of the homosexual characters or the author, but instead to be directed at pushing the reader to battle his or her own prejudices and feelings of shame (which the reader may feel "for" the depicted characters). Often enough this kind of shame felt "for" someone else causes offensive and aggressive behaviour, in this case - homophobic. At the same time, Witkowski demonstrates that demonising behaviours

9 Cf. "Bezwstydem jest zamęt, który sprawia, że nie panujemy nad ciałem, że tracimy trwałą i wyraźną osobowość." (Bataille 2007: 21) 
and upholding taboos results in demonstrating perpetual blindness to the heart of the problem. The narrator of Lovetown lounges on the beach and comments:

I entice them for their stories... I want them to become my storytellers, like the ones in Pasolini's Salo. And every day they'll tell an even more perverted tale for the State, standing at the piano, in front of the burning doors. It's a faggot Decameron I'm trying to turn out here. The only problem is there's no such a thing as sin any more. It's vanished, soaked up by the sand like a couple of drops they've flicked off themselves after coming out of the sea. Where did it vanish? When? (Witkowski 2011: 81)

If in Gretkowska's work the sensation of shame is rarely called by name, in Witkowski's prose this word possibly never appears; still, in the reader's reception, both texts hugely concentrate on getting accustomed to, taming and overcoming this emotion. In Gretkowska and Witkowski's work, a significant role is played by irony, humour and distance towards the problems described - despite opting for first-person narration, which tends to bring the reader closer. The author hides behind the narrator, juggling autobiographical allusions from a safe distance. The convention of openness and honesty legitimises the use of colloquialisms and vulgarisms. Thus, not just the subject matter, but also the language of the discussed novels might be described as "shameless" - that is, falling outside the boundaries of good taste, even if such assessments seem naïve and anachronistic. Social and aesthetic norms, even if liberalised, remain in force, ergo transgression and provocation are still possible. Although these days we are increasingly ashamed not of breaking rules, but of shame itself and its automatic appearance. Feelings of shame accompany the readers who, with pleasure bordering on the perverse, devour especially texts viewed as obscene, scandalous, forbidden, and indecent and inducing both embarrassment and excitement. If the writer displays exhibitionistic inclinations, the reader is by nature a voyeur, a nosy onlooker (cf. Anz, 1998) especially interested in things intimate and hidden. As Agata Bielik-Robson points out: "Podglądanie innych w sytuacjach, które filozofia określa jako graniczne - narodziny, miłość i śmierć - okazuje się potrzebą nieodpartą zdradzaną już przez osobniki najmłodsze, co nieomylnie wskazuje na jej niezmienny, uparcie naturalny charakter. [Watching others in situations defined by philosophy as thresholds - birth, love and death - turns out to be an irresistible need, exhibited already by the youngest individuals, which clearly points to its unchanging, stubbornly natural character]" (Bielik-Robson 2000). The transgressive experiences mentioned above are closely linked to the bodily 
dimension of existence and belong to the set of motifs traditionally viewed as shameful. Their attractiveness and almost magical appeal results from the fact that they reveal "a fragment of peculiar and untamed being (...) that which we do not understand, that which crosses the boundaries of our understanding" (Bielik-Robson 2000). The thirst for knowledge to which Bielik-Robson refers may be, thanks to literature, satiated within safe, aesthetically defined boundaries. The exhibitionist-voyeur game played by author and reader rests outside the commonplace moral assessments and its shamelessness becomes its virtue.

\section{Bibliography}

Anz Thomas 1998, Literatur und Lust. Glück und Unglück beim Lesen, München: dtv.

Bataille Georges 2007, Erotyzm, trans. Maryna Ochab, Gdansk: słowo/obraz terytoria.

Bielik-Robson Agata 2000, „Podglądanie, czyli głód rzeczywistości”, Tygodnik Powszechny Magazyn Kulturalny no. 6 (44).

Carr-Gomm Philip 2012, A Brief History of Nakedness, London: Reaktion Books.

Chu Victor, de Las Heras Brigitta 1994, Scham und Leidenschaft, Zürich: Kreuz Verl.

Demmerling Christoph, Landweer Hilge 2007, Philosophie der Gefühle, Stuttgart: Metzler Verl.

Dilthey Wilhelm 1974, Przeżycie i poezja, trans. O. Dobijanka, [in:] Teoria badań literackich za granica. Antologia, ed. S. Skwarczyńska, t. II, Cracow: Wydawnictwo Literackie.

Frevert Ute 2013, Vergängliche Gefühle, Göttingen: Wallstein Verl.

Gretkowska Manuela 2012, Polka, Warsaw: WAB.

Kuźma Erazm 2006, Od wyrazu do intymności, [in:] Intymność wyrażona, eds. M. Kisiel, M. Tramer, Katowice: Wyd. Uniwersytetu Śląskiego.

Menninghaus Winfried 2009, Wstręt. Teoria i historia, trans. Grzegorz Sowiński, Cracow: Universitas.

Nasiłowska Anna 1995, Domino. Traktat o narodzinach, Warsaw: OPEN.

Nasiłowska Anna 2002, Księga poczatku, Warsaw: WAB.

Nęcka Agnieszka 2006: Granice przyzwoitości. Doświadczenie intymności w polskiej prozie najnowszej, Katowice: PARA.

Nussbaum Martha C. 1990, Love's Knowledge. Essays on Philosophy and Literature, New York: Oxford University Press.

Psychologia emocji 2005, eds. M. Lewis, J. Haviland-Jones, Gdansk: Gdańskie Wydawnictwa Pedagogiczne.

Sadkowski Wacław 1987, „Wzlot i upadek. Rewolucja seksualna od Henry Millera do Wiliama Burroughsa", Literatura na Świecie, no. 5-6.

Sartre Jean Paul 2003, Being and Nothingness: An Essay on Phenomenological Ontology, Oxford-New York: Routledge Classics. 
Approaches Towards Shame...

Scheler Max 2003, O wstydzie i poczuciu wstydu, [in:] Wstyd i nagość, ed. M. Grabowski, Toruń: Wydawnictwo Uniwersytetu Mikołaja Kopernika.

Simmel Georg 2006, Mentalność mieszkańców wielkich miast, [in:] Most i drzwi, trans. Małgorzata Łukasiewicz, Warsaw: Oficyna Naukowa.

Tuwim Julian 1987, Aforyzmy i limeryki, Warsaw: Wydawnictwo Artystyczne i Filmowe.

Warchala Michał 2006, Autentyczność i nowoczesność. Idea autentyczności od Rousseau do Freu$d a$, Cracow: Universitas.

Witkowski Michał 2011, Lovetown, trans. W. Martin, London: Portobello Books. 